\title{
Discrimination of mass movement in Alpine Slovenia using PSInSAR data
}

\author{
M. Komac \& M. Bavec \\ Geological Survey of Slovenia, Slovenia
}

\begin{abstract}
Using a relatively new method called the PSInSAR (Permanent Scatterer Interferometry) technique, mass movements in an area that spreads over $700 \mathrm{~km}^{2}$ and lies in the Julian Alps and the foreland (north-western Slovenia) were assessed. The research area forms the eastern flank of the Alpine arch and is tectonically still active. For analytical purposes 57 images of descending orbit from satellites ERS 1 and ERS 2 were used. The time span of the acquired images was from April 1992 to December 2000. The average signal reflector (PS) density for the area was $23 / \mathrm{km}^{2}$. Altogether 16,304 permanent scatters were detected. A time series of displacements was acquired for the best $10 \%$ (1,646 PS). The results show a constant uplift of the Southern Alps and indicate that the uplift is of a higher magnitude than had been considered until now - in some cases almost five times higher. The relative uplift in relation to the reference point in the Alpine foreland ranges up to $3.35 \mathrm{~mm}$ per year. An uplift of this magnitude is clearly related to processes of active tectonics including coseismic phenomena. Tectonic subsidence on the other hand is difficult, or in some cases impossible to discriminate from landslides and other processes of mass wasting.
\end{abstract}

Keywords: permanent scatterer, InSAR, mass movement, tectonics, Julian Alps, Slovenia.

\section{Introduction}

Slovenia lies in the eastern flank of the Alpine arch and the active tectonics is believed to be the primary driving force of mass movement in the region. This is especially true for the north-western part of Slovenia where the research area was 
chosen due to its known neotectonic activity [1-3] and numerous landslides, rockfall and debris flow occurrences [4]. Tectonic activity is defined by the stress filed with principal stress axis $\left(\sigma_{1}\right)$ oriented approximately in N-S direction [3, 5-7]. Several major active right lateral strike-slip faults dissect the area (Idrija, Sava and Ravne fault) along with the South Alpine thrust [2, 8, 9] and the thrusts of the secondary order (Julian nappe, Tolmin nappe, Trnovo nappe; after [5]). The broader area is characterized by medium seismic activity [1]. During the InSAR data acquisition, between April 1992 and December 2000, a major earthquake occurred in the research area with a magnitude of $\mathrm{MW}=5.6$ $[2,9,10]$.

Mesozoic carbonate rocks prevail while successions of alternating clastic, and carbonate rocks (e.g. flysch) are also abundant in the area. The network of fluvial and glacial valleys is filled with terrestrial sediments of Quaternary age [11-13].

The advanced satellite radar Permanent (also persistent) Scatterer Interferometry technique (PSInSAR) used for this analysis was reported to enable highly accurate monitoring of relative vertical displacement velocities of the observed surfaces and grounds [14-18]. The technique is also very useful in geology for monitoring coseismic and aseismic tectonic displacements [19-24], slow moving landslides [14, 25, 26], and ground swelling or subsidence [27-30].

\section{Research area and data used}

The assessment of tectonic and landslide mass displacement was carried out in the research area in the north-western part of Slovenia, spreading between Most na Soči $\left(13^{\circ} 46^{\prime} 50^{\prime \prime} \mathrm{E}, 46^{\circ} 7^{\prime} 41^{\prime \prime} \mathrm{N}\right)$ to the South, Kranjska Gora $\left(46^{\circ} 29^{\prime} 23^{\prime \prime}\right.$, $\left.13^{\circ} 47^{\prime} 7^{\prime \prime} \mathrm{E}\right)$ to the North, Srpenica $\left(13^{\circ} 33^{\prime} 12^{\prime \prime} \mathrm{E}, 46^{\circ} 16^{\prime} 15^{\prime \prime} \mathrm{N}\right)$ to the west and Bohinjska Bistrica $\left(46^{\circ} 16^{\prime} 1^{\prime \prime} \mathrm{N}, 13^{\circ} 57^{\prime} 3^{\prime \prime} \mathrm{E}\right)$ to the east (Fig. 1). The area includes the highest areas of Slovenia and roughly half of Triglav National Park. The average altitude of the area is 1,157 m.a.s.l., given the highest peak is at 2,864 and the lowest altitude is 141 m.a.s.l.

To assess the tectonic and landslide mass movements in the research area, geological [11, 12] and structural data, digital elevation model [31], landslide occurrences [4], seismic activity [1-3,5-7, 9, 10,32], rainfall [33] and "geophysical" (Permanent Scatterer InSAR; [34]) data were used. Analyses were focused on assessment of applicability of the PSInSAR technique for monitoring the relative uplift or subsidence of masses, either as a consequence of endogenic (tectonics) or exogenic (gravitation and climate driven) forces.

For the purpose of presenting the analyses, 57 images from the descending orbits of ERS-1 and ERS-2 satellites were used. These images were acquired between 21 April 1992 and 29 December 2000. The one taken on 26 September 1997 was selected as the reference image [34]. 


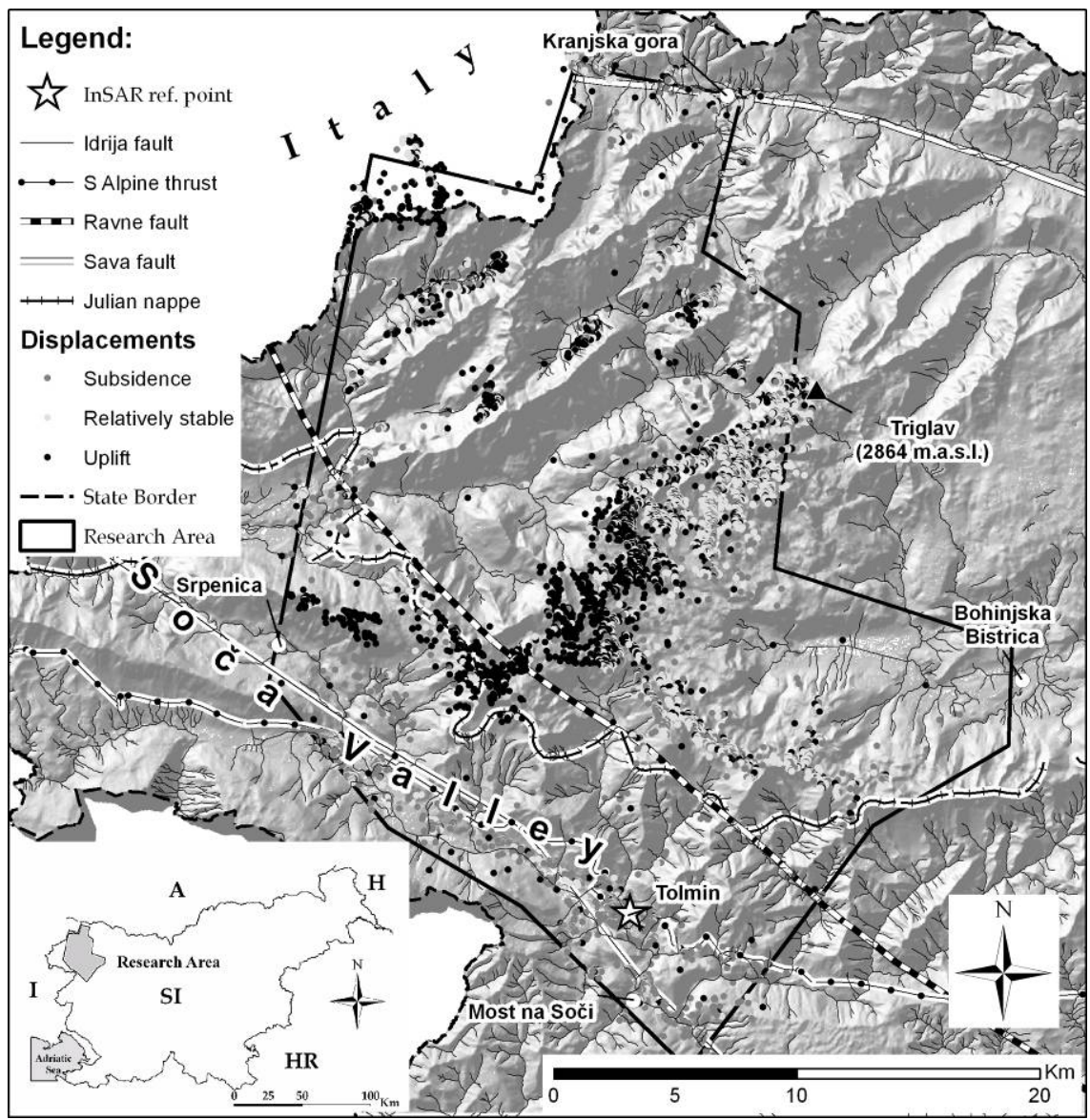

Figure 1: The research area is located in the north-western part of Slovenia, bordering Italy and covering the south-eastern flank of the Alps the area of the Julian Alps. The reference point was set in the town of Tolmin, represented in Fig. 1 by a star.

\section{Permanent scatterer InSAR}

Radar interferometry is a technique that has been successfully applied in different fields. The Earth's topography can be observed with interferometry by using two approaches, with either one or two passes (overflights). In the first approach emission and reception antennas are placed on the same platform (aeroplane or satellite), while in the second approach, which is usually used in satellite acquisition, the same or identical platform overflies the same area with a time lag from slightly shifted orbits $[35,36]$. Permanent Scatterer Interferometry (PSInSAR) is a relatively new technique that enables highly accurate monitoring 
of relative vertical displacement velocities of the observed surfaces and grounds in the line-of-sight of the satellite signal. In the case of ERS satellites the declination of the radar signal from vertical is $23^{\circ}$. InSAR data have limitations such as changes in the reflection of objects or areas, atmospheric influences (decorrelation), and signal disturbances. A statistical minimization of these disturbances can be achieved by using radar data over a longer period and determining coherent radar targets - permanent scatterers. This technique is named Permanent Scatterer Interferometric Synthetic Aperture Radar or PSInSAR [18]. Fig. 2 shows the basic principles of InSAR permanent scatterer operation.

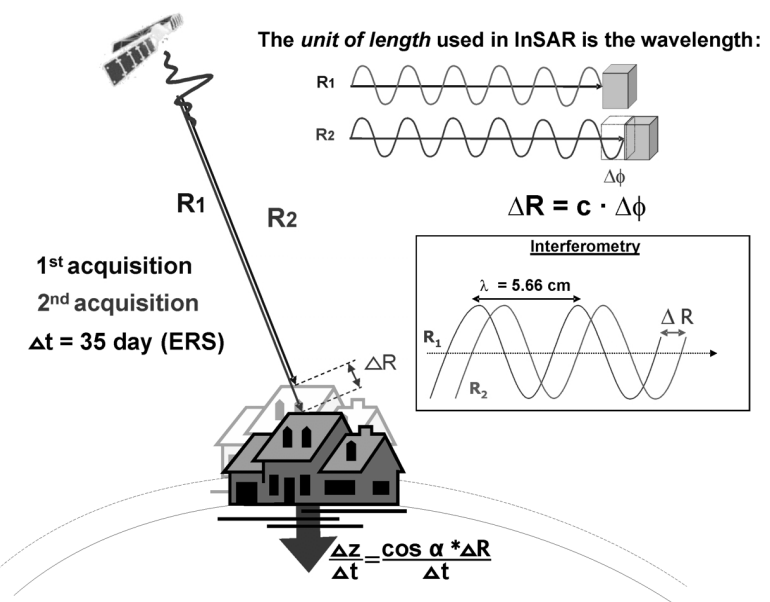

Figure 2: $\quad$ Basic principles of PSInSAR (Permanent Scatterer Interferometric Side Aperture Radar) operation (after [18]).

Satellites (ERS-1 and ERS-2), providing images that are the main source for PSInSAR, have an orbit cycle of 35 days. Displacements $(\Delta z)$ in the line of sight, which are during this period smaller than half of the wavelength used $(5.66 \mathrm{~cm})$, can be registered on the basis of wave difference $(\Delta \Phi)$ of the backscattered signal. The best results are expected to be achieved in urban areas; those with little or no vegetation and where there are rocky outcrops. This technique is useful for detecting and monitoring vertical displacements of the surface, but caution is necessary when analysing PS data since horizontal movements can blur or intensify actual vertical displacements.

Based on the preliminary data analyses and geological prospect for the reference point (stable or "zero" displacement point), a location near the town of Tolmin was chosen. The location reference point is $46^{\circ} 11^{\prime} 3.44^{\prime \prime} \mathrm{N}$, $13^{\circ} 44^{\prime} 45.12^{\prime \prime} \mathrm{E}$ and its overall coherence 0.84 . The average density of permanent scatterers is $23 / \mathrm{km}^{2}$, and the minimum density required for analysis $15 / \mathrm{km}^{2}$. Average displacements in the line-of-sight (LOS) were determined for the whole target population. Altogether 16,304 permanent scatterers with a coherence 
higher than 0.5 were detected. For the most reliable $10 \%$ of the population (1,646 PS with a coherence higher than 0.74) the displacement data of all 57 acquisitions were calculated (temporal measurements). For these targets, the time series of displacements from 1992 to 1994 and again from 1995 to 2000 were derived. All displacements referred to in this text are relative and as such related to the status of the reference point in the town of Tolmin. Although the reference point is considered as stable, we emphasize there are no absolute stable points in the area (cf. [7]), and an awareness of this relativity is crucial for comprehending the results. Negative velocities do not necessarily represent subsidence, but possibly only its slower uplift according to the reference point.

\section{Results and discussion}

\subsection{Tectonic displacement}

In order to assess the tectonic influence to mass movement in the research area, the PS data were analysed and major structural features of the area were taken into account. Considering only the best $10 \%$ of PS $(n=1646)$, the maximum velocities towards the satellite in the line-of-sight range up to $6.65 \mathrm{~mm} /$ year and maximum velocities away from the satellite range up to $(-) 3.30 \mathrm{~mm} / \mathrm{year}$. The relative vertical components of the velocities are 6.12 and (-)3.06 mm/year, respectively.

Table 1 shows the uplifting velocities for the PS with temporal measurements $(\mathrm{n}=91)$ situated in the area of the Julian Alps (Julian nappe). The region has already been confirmed to uplift [7,36]. The estimation of relative vertical velocities of 91 PS was based on an average uplifting velocity for each PS criterion. The most conservative approach that encompasses all uplifting PS $(n=91)$ shows that on average the Julian Alps uplift by one millimetre annually. Considering only the most extreme PS with uplifting velocities of over $2.43 \mathrm{~mm} /$ year (upper $2.5 \%$ of population; $\mathrm{n}=5$ ) the estimation of average vertical uplift of the Julian Alps is $3.35 \mathrm{~mm} /$ year in relation to the reference point. The velocity is unexpectedly high so the possibility of data error should not be neglected. This dilemma will be solved in future research.

Fig. 3 shows a comparison of average vertical component displacements of 58 PS in the village of Drežnica, situated near the Ravne fault and the Julian nappe fault trace, and average relative vertical component displacements of all uplifting PS situated in the Julian nappe $(n=91$; PS with average displacement velocity above $0.0 \mathrm{~mm} /$ year). The village of Drežnica "subsides" with a velocity of $1.4 \mathrm{~mm} /$ year. The extraordinary displacements can be observed between 28 February and 9 May 1997. A similar but less obvious displacement in an opposite direction occurs in the Julian Alps. A detailed analysis of seismic activity in the limited area around Drežnica indicates that several earthquakes occurred in the autumn 1996 to spring 1997 period (29 Nov. 1996 (ML = 1.6) and 15 Feb. 1997 (ML = 2.3) [32], which may have caused the described displacements. In the period between 15 March and 18 April 1996 synchronous yet again opposite orientated displacements occurred. A similar but reverse 
Table 1: $\quad$ Average daily or annual displacements (D) for: (a) PS with uplift velocity above $2.43 \mathrm{~mm} / \mathrm{y}$; and (b) PS with uplift velocity above $0.0 \mathrm{~mm} / \mathrm{y}$.

\begin{tabular}{|l|c|c|c|}
\hline PS, where & $\Delta h(\mathrm{~mm})$ & $\mathrm{D}(\mathrm{mm} / \mathrm{d})$ & $\mathrm{D}(\mathrm{mm} / \mathrm{y})$ \\
\hline a) $\mathrm{D}>2.43 \mathrm{~mm} / \mathrm{y}(\mathrm{n}=5)$ & 29.16 & 0.0092 & 3.35 \\
\hline b) $\mathrm{D}>0.0 \mathrm{~mm} / \mathrm{y}(\mathrm{n}=91)$ & 8.21 & 0.0026 & 0.94 \\
\hline
\end{tabular}

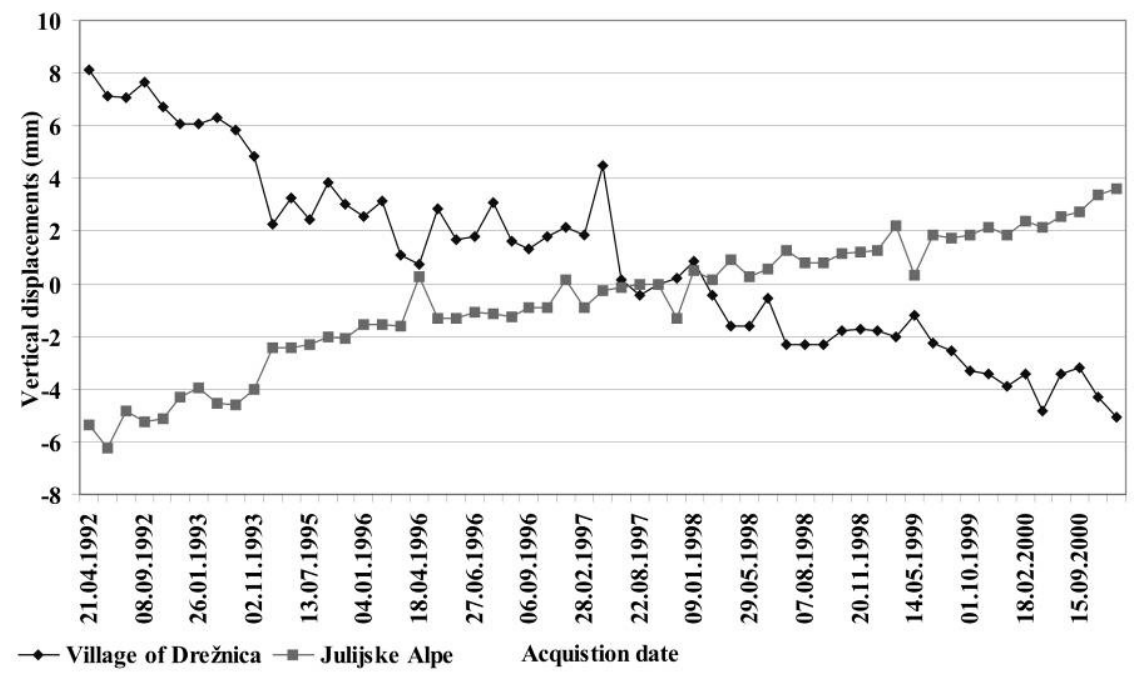

Figure 3: Comparison of average relative vertical component displacements of 58 PS in the village of Drežnica and average relative vertical component displacements of all uplifting PS situated in the Julian nappe $(\mathrm{n}=91$; PS with average displacement velocity above $0.0 \mathrm{~mm} /$ year), shown in blue and red respectively. All displacements are given in $\mathrm{mm}$ and represent the vertical component.

phenomenon occurs between 9 April and 14 May 1996. When comparing displacements to seismic data [32], the mentioned displacements can be related to coseismic surface movement. The cause of intensive displacements in April 1996 is unknown. It could be the consequence of a systematic error, or be connected to energy accumulation prior to the Friuli 12 April 1996 earthquake and post-earthquake tremors three days later $(\mathrm{ML}=4)$ [32]. 


\subsection{Coseismic surface displacements as a consequence of the "Easter earthquake" on 12 April 1998}

During PSInSAR monitoring, a major earthquake with a magnitude of MW $=5.6$ occurred in the central part of the research area [2, 9, 10]. Fig. 4 shows the locations of some PS that have been affected by the 1998 "Easter earthquake". The time displacements are shown in Fig. 5 where only the displacement time span from January to September 1998, covering several months before and after the 1998 Easter earthquake, is shown. The surface displacements related to the earthquake are clearly visible. First a subsidence of an average $8.4 \mathrm{~mm}$ occurred somewhere between two and 10 weeks after the earthquake, followed by an uplift of an average $12.3 \mathrm{~mm}$. The time lag of the displacements could be the consequence of post-earthquake surface "equilibration" or systematic error of data during their processing, but the possibility of the latter is negligible.

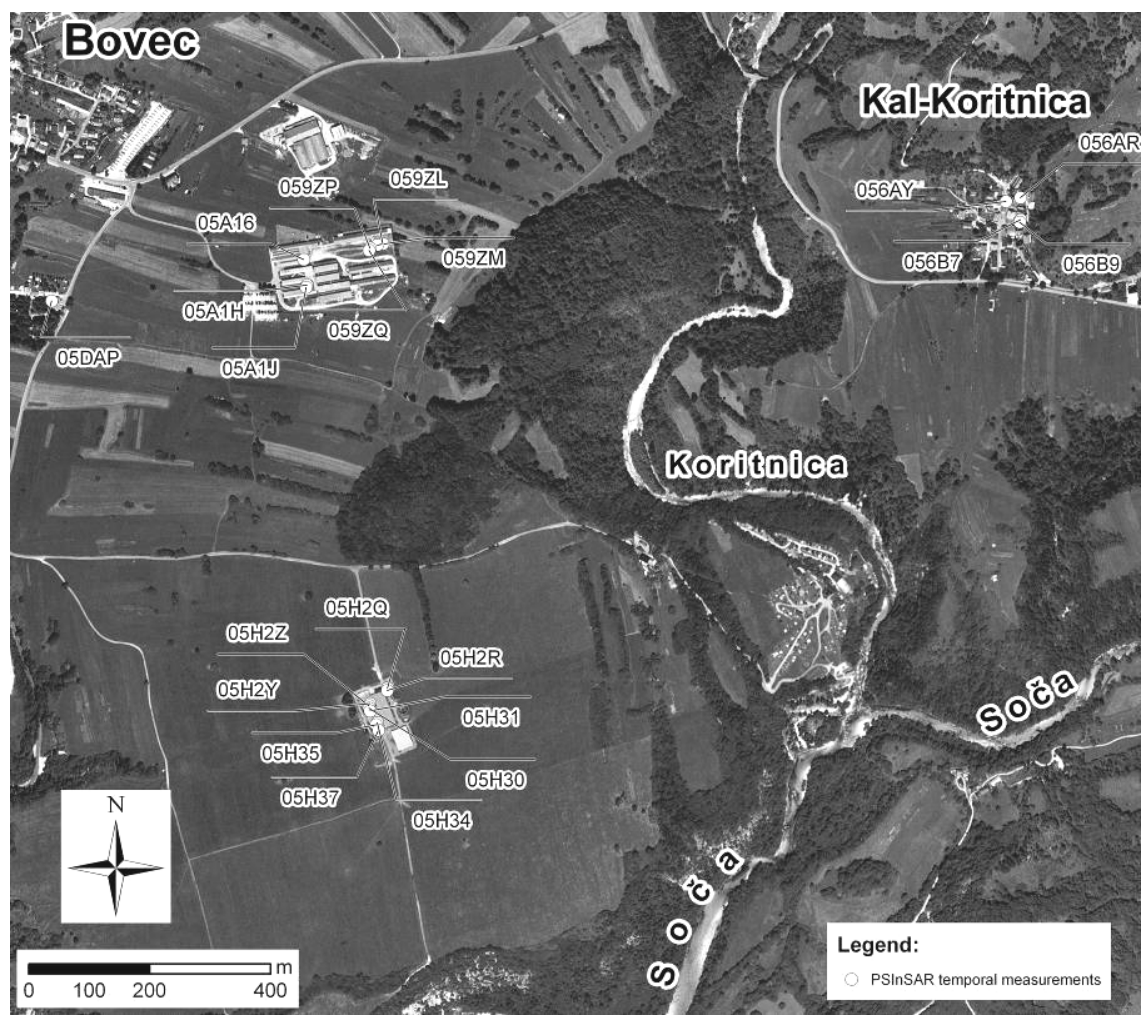

Figure 4: Eastern part of the Bovec basin area where relative vertical component displacements have been measured. Red points represent PS for which temporal displacements are show below. 


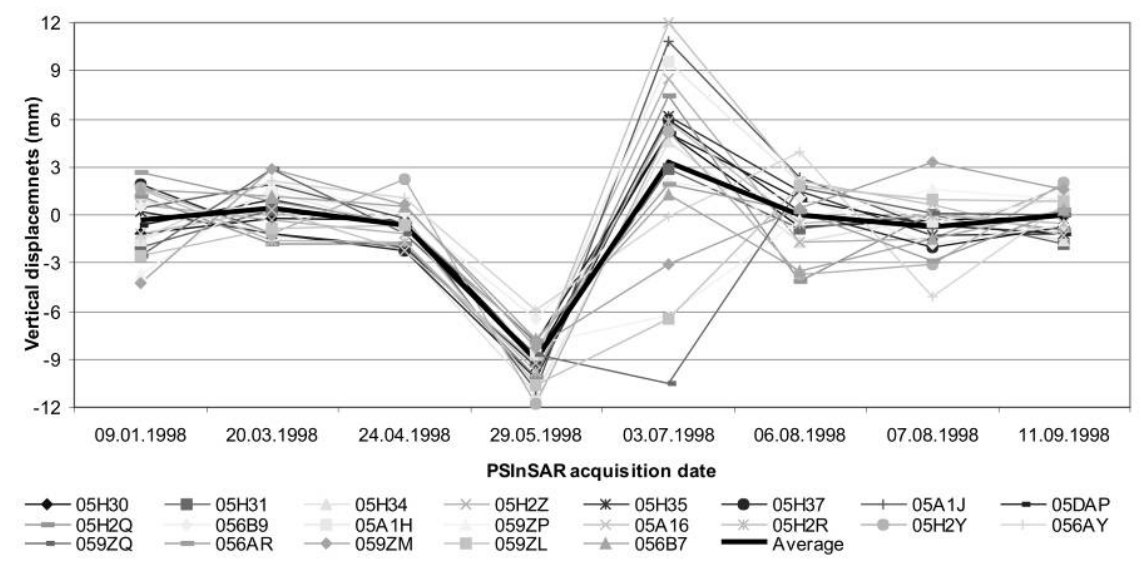

Figure 5: Relative vertical component displacements of PS situated in the eastern part of the Bovec basin according to reference point. All displacements are given in $\mathrm{mm}$ and projected to the vertical axis. "Easter earthquake" happened on April 12th 1996.

\section{Conclusions}

The origin of uplifting is more or less clear: it is the consequence of active tectonics with the extreme displacements probably being the result of locally limited conditions. On the contrary, the "subsidence" or moving downwards is more of a complex nature, being a result of tectonics and gravitation acting simultaneously. The most extreme movements are most likely indications of gravitational mass movements - landslides.

The Julian Alps are uplifting, but estimates from PS measurements differ substantially from earlier estimates [37]. Considering the most conservative approach, it is roughly the same $(1 \mathrm{~mm} / \mathrm{y})$, but considering the fastest uplifting PS, the Alps are uplifting with velocities of up to $3.35 \mathrm{~mm} / \mathrm{y}$. These values have to be interpreted very carefully as the horizontal displacements that are believed to prevail here may blur real vertical displacements noticeably.

Further investigations focus on long-term geodetic ground, and GPS measurements. InSAR data from ascending orbits will also be acquired to cover the south-facing slopes where the majority of landslides in the area occur.

\section{Acknowledgements}

The project ClimChalp was co-funded by EU Cohesion funds in the frame of Interreg III B - Alpine Space programme and financially supported by Environmental Agency of the Republic of Slovenia. 


\section{References}

[1] Poljak, M. Živčić, M. \& Zupančič, P., The seismotectonic characteristics of Slovenia. Pure Applied Geophysics, 157, p.p. 27-55, 2000.

[2] Zupančič, P., Cecić, I., Gosar, A., Placer, L., Poljak, M. \& Živčić, M., The earthquake of 12 April 1998 in the Krn Mountains (Upper Soča valley, Slovenia) and its seismotectonic characteristics. Geologija, 44(1), p.p. 169-192, 2001.

[3] Grenerczy, G., Sella, g., Stein, S. \& Kenyeres, A., Tectonic implications of the GPS velocity field in the northern Adriatic region. Geophys. Res. Lett., 32, article L16311, 2005, doi: 10.1029/ 2005GL022947.

[4] Komac, M., Šinigoj, J., Krivic, M., Kumelj, Š., Hribernik, K. \& Vehovec, A., Pregled in analiza podatkov v obstoječih bazah plazov za novelacijo baze GIS_UJME”. Geological Survey of Slovenia, pp. 1-51, Ljubljana, 2005.

[5] Placer, L., Contribution to the macrotectonic subdivision of the border region between Southern Alps and External Dinarides. Geologija, 41, p.p. 223-255, 1998.

[6] Weber, J., Vrabec, M., Stopar, B., Pavlovčič Prešeren, P. \& Dixon, T., The PIVO-2003 experiment: a GPS study of Istria peninsula and Adria microplate motion, and active tectonics in Slovenia. The Adria microplate: GPS geodesy, tectonics and hazards. NATO Science Series, $I V$, Earth and Environmental Sciences, 61, Pinter, N., Grenerczy, G., Weber, J., Stein, S., Medak, D. (eds), Springer, p.p. 305-320, 2006.

[7] Rižnar, L., Koler B. \& Bavec, M., Recentna aktivnost regionalnih geoloških struktur v zahodni Sloveniji. Geologija, 50(1), Ljubljana, 2007.

[8] Poljak, M., Structural-Tectonical Map of Slovenia 1:250.000. Geological Survey of Slovenia, 2000.

[9] Bajc, J., Aoudia, A., Sarao, A. \& Suhadolc, P., The 1998 Bovec-Krn mountain (Slovenia) earthquake sequence, Geophys. Res. Lett., 28, p.p. 1839-1842, 2001.

[10] Gosar, A., Stopar, R., Car, M. \& Mucciarelli, M., The earthquake on 12 April, 1998 in Krn mountains (Slovenia): Ground motion amplification study using microtremorsand modelling based on geophysical data. Journal Appl. Geophys., 47(2), p.p. 153-167, 2001.

[11] Buser, S., Basic geological map of SFRY, sheet Tolmin and Udine, $1: 100.000$. Federal Geological Survey, Belgrade, 1987.

[12] Jurkovšek, B., Basic geological map of SFRY, sheet Beljak and Pontebba, $1: 100.000$. Federal Geological Survey, Belgrade, 1987.

[13] Bavec, M., Tulaczyk, S.M., Mahan, S.A. \& Stock, G. M., Late Quaternary glaciation of the Upper Soča River Region (Southern Julian Alps, NW Slovenia). Sedimentary geology. 165(3/4), p.p. 265-283, 2004.

[14] Ferretti, A., Prati, C. \& Rocca, F., Permanent Scatterers in SAR Interferometry. IEEE Transactions On Geoscience And Remote Sensing, 39(1), p.p. 8-20, 2001. 
[15] Ferretti, A., Bianchi, M., Prati C., \& Rocca, F., Higher-Order Permanent Scatterers Analysis. EURASIP Journal on Applied Signal Processing, 20, p.p. 3231-3242, 2005.

[16] Bürgmann, R., Hilley, G., Ferretti A., \& Novali, F., Resolving vertical tectonics in the San Francisco Bay Area from permanent scatterer InSAR and GPS analysis. Geology, 34(3), p.p. 221-224, 2006.

[17] Dixon, H.T., Amelung, F., Ferretti, A., Novali, F., Rocca, F., Dokka, R., Sella, G., Kim, S.W., Wdowinski S. \& Whitman, D., Subsidence and flooding in New Orleans. Nature, 441, p.p. 587-588, 2006.

[18] Ferretti, A. \& Crespa, S., Advances in Differential SAR Interferometry: from DInSAR to PSInSARTM. CSTARS "Height" Workshop October, 24th 2006, Miami, Florida, 2006.

[19] Massonnet, D., Rossi, M., Carmona, C., Adragna, F., Peltzer, G., Feigl K. $\&$ Rabaute, T., The displacement field of the Landers earthquake mapped by radar interferometry. Nature, 364, 1993.

[20] Massonnet, D., Feigl, K.L., Rossi, M. \& Adragna, F., Radar interferometric mapping of deformation in the year after the Landers earthquake. Nature, 369, 1994.

[21] Dixon, T.H., SAR interferometry and surface change detection (ed.), Report of a Workshop Held in Boulder, Colorado: February 3-4, 1995, University of Miami, 1995. http://southport.jpl.nasa.gov/ scienceapps/dixon/index.html

[22] Peltzer, G., Rosen, P.A., Rogez, F. \& Hudnut, K., Postseismic rebound in fault stepovers caused by pore fluid flow. Science, 273, 1996.

[23] Massonnet, D., Thatcher, W. \& Vadon, H., Detection of post-seismic fault zone collapse following the Landers earthquake. Nature, 382, 1996.

[24] Peltzer, G., Crampé, F. \& King, G., Evidence of the nonlinear elasticity of the crust from Mw 7.6 Manyi (Tibet) earthquake. Science, 286, 1999.

[25] Colesanti, C., Ferretti, A., Prati, C. \& Rocca, F., Monitoring Landslides and Tectonic Motion with the Permanent Scatterers Technique. Engineering Geology, 68, p.p. 3-14, 2003a.

[26] Hilley, G.E., Bürgmann, R., Ferretti, A., Novali, F. \& Rocca, F., Dynamic of slow-moving landslides from permanent scatterer analysis. Science, 304/5679, p.p. 1952-1955, 2004.

[27] Carnec, C. \& Delacourt, C., Three years of mining subsidence monitored by SAR interferometry, near Gradane, France. Journal of Applied Geophysics, 43, p.p. 43-54, 2000.

[28] Ferretti, A., Prati, C. \& Rocca, F., Nonlinear subsidence rate estimation using permanent scatterers in differential SAR interferometry. IEEE Trans. Geosci. Remote Sensing, 38/5, p.p. 2202-2212, 2000.

[29] Colesanti, C., Ferretti, A., Novali, F., Prati, C. \& Rocca, F., SAR Monitoring of Progressive and Seasonal Ground Deformation Using the Permanent Scatterers Technique. IEEE Transactions on Geoscientific Remote Sensing, 41, p.p. 1685-1700, 2003 b.

[30] Vasco, D.W. \& Ferretti, A., On the use of quasi-static deformation to understand reservoir fluid flow. Geophysics, 70(4), p.p. O13-O27, 2005. 
[31] SMA, Digital elevation model. The Surveying and Mapping Authority of the Republic of Slovenia, Ljubljana, 2001.

[32] Živčić, M., Earthquake catalogue. Office for seismology and geology, Agency of Republic of Slovenia for the environment, Unpublished, 2006.

[33] ARSO, Podatki o padavinah, Archives. Agencija RS za okolje, Urad za meteorologijo Ministrstva za okolje, prostor in energijo, Ljubljana, 2005. http://eionet-si.arso.gov.si/Dokumenti/GIS/splosno

[34] Bianchi, M. \& Ferretti, A. Processing Report Slovenia, western area ERS descending dataset (06.008C). Land deformation monitoring using satellite radar data processed with the Permanent Scatterers Technique (POLIMI PS TechniqueTM), Tele-Rilevamento Europa, 30 p., Milano, 2006.

[35] Oštir, K., Analiza vpliva združevanja radarskih interferogramov na natančnost modelov višin in premikov zemeljskega površja: doktorska disertacija. Univerza v Ljubljani, 175 p., Ljubljana, 2000.

[36] Oštir, K., Daljinsko zaznavanje, Založba ZRC, pp. 250, Ljubljana, 2006.

[37] Rižnar, I., Koler, B. \& Bavec, M., Identifikacija potencialno aktivnih struktur vzdolž reke Save na podlagi topografskih podatkov in podatkov nivelmanskega vlaka. Geologija, 48(1), p.p. 107-116, Ljubljana, 2005. 